\section{Creeping Bentgrass and Perennial Ryegrass Seedling Tolerance to Bispyribac-sodium}

\author{
Peter H. Dernoeden ${ }^{2}$ and Steven J. McDonald ${ }^{1}$ \\ Department of Plant Science and Landscape Architecture, University of \\ Maryland, 1112 H.J. Patterson, College Park, MD 20742
}

\author{
John E. Kaminski \\ Department of Plant Science, University of Connecticut, Storrs, CT 06269
}

Additional index words. Agrostis stolonifera, Lolium perenne, Velocity, Prograss bluegrass seedlings in a greenhouse study. They observed that BPS showed little selectivity between species and concluded that the herbicide was too phytotoxic to apply to immature CBG. Ethofumesate, however, was reported to be safe to apply to PRG seedlings 6 weeks after overseeding into bermudagrass (Cynodon spp.) (Yelverton and McCarty, 2001). Kaminski et al. (2004) found that ETHO was injurious to CBG seedlings but could be used without long-term negative effects when applied 4 weeks after seedling emergence in Maryland. The objectives of this field study were to determine the tolerance of CBG and PRG seedlings to BPS.

\section{Materials and Methods}

The study was initiated in Maryland in 2004 and was elaborated on in 2005 and repeated in Maryland and Connecticut. The Maryland site is situated in the transition zone, whereas the Connecticut site is in the temperate region. The transition zone is the boundary between temperate and subtropical climates in the eastern United States (Turgeon, 2008). Most BPS and ETHO rates evaluated were within label recommendations (Anonymous, 2005a, 2005b).

Maryland 2004. A seed bed was prepared by tilling and hand-raking. Separate blocks were seeded to either 'Southshore' CBG $\left(50 \mathrm{~kg} \cdot \mathrm{ha}^{-1}\right)$ or 'Brighstar' PRG (200 kg.ha $\left.{ }^{-1}\right)$ on 20 Aug. 2004. After seeding, the site was rolled and kept moist until most seedlings had emerged. A complete 18-18-18 fertilizer [ 25 $\mathrm{kg} \cdot \mathrm{ha}^{-1}$ nitrogen $\left.(\mathrm{N})\right]$ was applied to the seed bed at seeding and an additional $50 \mathrm{~kg} \cdot \mathrm{ha}^{-1} \mathrm{~N}$ from urea was applied 1 Oct. 2004. Three weeks after seedling emergence, mowing was initiated to a height of $5.0 \mathrm{~cm}$. Mowing height was lowered gradually to $\approx 2.5 \mathrm{~cm}$ by mid-October but could not be lowered further as a result of an uneven seed bed. Bispyribacsodium and ETHO treatments were applied initially on 24 Sept. [i.e., $\approx 4$ weeks after seedling emergence (WASE)] when CBG had four to eight tillers and PRG had two to four tillers. Dates and rates of application are footnoted in Table 1 .

Maryland 2005. A mature stand of CBG was treated with glyphosate [N-(phosphonomethyl)glycine] on 24 Aug. 2005. On 7 Sept., the area was vertical cut in two directions with half the area seeded to either 'Providence' CBG (50 kg.ha $\left.{ }^{-1}\right)$ or 'Catalina II' PRG (250 $\left.\mathrm{kg} \cdot \mathrm{ha}^{-1}\right)$. The area was kept moist and the majority of seedlings of both species had emerged by 16 Sept. Both sites received 50 $\mathrm{kg} \cdot \mathrm{ha}^{-1} \mathrm{~N}$ from urea on 6 and 29 Sept. and an additional $50 \mathrm{~kg} \cdot \mathrm{ha}^{-1} \mathrm{~N}$ from an 18-2-18 fertilizer on 21 Oct. and 15 Nov. 2005. In 2005, BPS rates were adjusted and seedlings were treated either 2 or 4 WASE. Application rates and dates are footnoted in the data tables. Herbicide treatments were applied $\approx 2(23$ Sept.) and 4 (6 Oct.) weeks after the first seedlings were observed on 12 Sept. When applied 2 WASE, CBG and PRG seedlings were five leaf to two tiller and three to four leaf, respectively. On 6 Oct. (i.e., 4 WASE),
Received for publication 18
for publication 6 June 2008 .

Mention of trademark, proprietary product, or vendor does not constitute a guarantee or warranty of the product by the U.S. Department of Agriculture and does not imply its approval to the exclusion of other products or vendors that also may be suitable.

${ }^{1}$ Former Graduate Student.

${ }^{2}$ To whom reprint requests should be addressed; e-mail pd@umd.edu
2004). Bispyribac-sodium [2,6-bis $(\{4,6-$
dimethoxy-2-pyrimidinyl $\}$ oxy)benzoic acid (BPS)] is labeled for use on CBG and PRG fairway turf and effectively contry Branham and Calhoun, 2005. Lycan Hart, 2006; McDonald et al., 2006). $\mathrm{d}$ after applications (McDonald et al., 2006) Once substantial annual bluegrass populaof CBG and PRG from seed, however, may be hampered by annual bluegrass competition. Although BPS is labeled for use on PRG fairways, its use on PRG maintained at been widely reported. Lycan and Hart (2005), however, found that a single application of BPS at rates ranging from 37 to $296 \mathrm{~g}$. only caused chlorosis in mature PRG maintained at a $4.0-\mathrm{cm}$ mowing height.

Although BPS is relatively safe on mature CBG grown at fairway height, its safety when applied to CBG and PRG seedlings has received little study. Hunter and Kealy (2005) investigated the effects of various BPS rates (22.7 to $136.2 \mathrm{~g} \cdot \mathrm{ha}^{-1}$ a.i.) on CBG and annual 
Table 1. 'Southshore' creeping bentgrass (CBG) and 'Brightstar' perennial ryegrass (PRG) cover in response to various rates of bispyribac-sodium (bispyribac) and ethofumesate applied $\approx 4$ weeks after seedling emergence, College Park, MD, 2004.

\begin{tabular}{|c|c|c|c|c|c|c|}
\hline \multirow[b]{2}{*}{ Herbicide } & \multirow[b]{2}{*}{$\begin{array}{c}\text { Rate }^{\mathrm{z}} \\
\left.\text { (g.ha }{ }^{-1} \text { a.i. }\right)\end{array}$} & \multicolumn{2}{|c|}{ CBG cover ${ }^{y}$} & \multicolumn{3}{|c|}{ PRG covery } \\
\hline & & 15 Oct. & 28 Nov. & 15 Oct. & $\begin{array}{l}25 \text { Oct. } \\
--(\%)\end{array}$ & 28 Nov. \\
\hline Bispyribac $80 \mathrm{WP}$ & 49 & $99 a^{x}$ & $100 \mathrm{a}$ & $95 \mathrm{ab}$ & $94 \mathrm{abc}$ & $96 \mathrm{~cd}$ \\
\hline Bispyribac $80 \mathrm{WP}$ & $49+49$ & 99 a & $100 \mathrm{a}$ & $97 \mathrm{a}$ & $96 \mathrm{ab}$ & $97 \mathrm{abc}$ \\
\hline Bispyribac $80 \mathrm{WP}$ & 74 & 99 a & $100 \mathrm{a}$ & $93 \mathrm{bc}$ & $93 \mathrm{bcd}$ & $96 \mathrm{abc}$ \\
\hline Bispyribac 80WP & $74+74$ & $99 \mathrm{a}$ & $100 \mathrm{a}$ & $95 \mathrm{abc}$ & $94 \mathrm{bcd}$ & $95 \mathrm{~cd}$ \\
\hline Bispyribac 80WP & 111 & $99 \mathrm{a}$ & $100 \mathrm{a}$ & 92 bc & $92 \mathrm{~cd}$ & $95 \mathrm{~cd}$ \\
\hline Bispyribac 80WP & 148 & $99 \mathrm{a}$ & $100 \mathrm{a}$ & $91 \mathrm{c}$ & $90 \mathrm{~d}$ & $94 \mathrm{~d}$ \\
\hline Ethofumesate $1.5 \mathrm{EC}$ & $840+840$ & $98 \mathrm{~b}$ & $99 \mathrm{a}$ & 99 a & $98 \mathrm{a}$ & $98 \mathrm{a}$ \\
\hline Untreated & - & $99 \mathrm{a}$ & $100 \mathrm{a}$ & $99 \mathrm{a}$ & $98 \mathrm{a}$ & $98 \mathrm{a}$ \\
\hline
\end{tabular}

${ }^{\mathrm{z}}$ All treatments were applied $\approx 4$ weeks after seedling emergence on 24 Sept. and sequential treatments were applied 18 Oct. 2004

${ }^{y}$ Cover was assessed visually on a $0 \%$ to $100 \%$ scale in which $0=$ entire plot area brown or dead and $100=$ entire plot area green.

${ }^{\mathrm{x}}$ Means in a column followed by the same letter are not significantly different $(P \leq 0.05)$ according to Tukey's protected least significant difference test.

CBG and PRG seedlings were two to five tiller and five leaf to three tiller, respectively. The site was first mowed to a height of $2.0 \mathrm{~cm}$ with a real mower on 30 Sept. Thereafter, the site was mowed once or twice weekly to a height of $1.2 \mathrm{~cm}$ with a walk-behind real mower and clippings were removed. Soil at both Maryland sites was a Keyport silt loam (fine-loamy, siliceous mesic Typic Hapludult) with a pH of 5.7 to 5.9 and $2.2 \%$ to $2.7 \%$ organic matter. In both years, studies were conducted at the University of Maryland Paint Branch Turfgrass Research Facility in College Park.

Connecticut 2005. Field evaluations were conducted at the University of Connecticut's Plant Science Research and Education Facility located in Storrs. Two separate areas were treated with glyphosate, tilled, and seeded to either 'Putter' CBG (49 kg.ha' $\left.{ }^{-1}\right)$ or 'Amazing' PRG (245 kg.ha $\left.{ }^{-1}\right)$ on 17 and 14 Sept. 2005, respectively. Soil at the CBG study site was a Paxton fine sandy loam (coarse loamy, mixed, active, mesic Oxyaquic Dystrudept) with a $\mathrm{pH}$ of 6.1 and $4.9 \%$ organic matter. For the PRG site, soil was a Woodbridge fine sandy loam (coarse loamy, mixed, active, mesic Aquic Dystrochrept) with a $\mathrm{pH}$ of 6.4 and $5.4 \%$ organic matter. Both areas were kept moist and the majority of seedlings had emerged by 22 Sept. Both sites received a total of $18 \mathrm{~kg} \cdot \mathrm{ha}^{-1} \mathrm{~N}$ on 30 Sept. from a 9-255 starter fertilizer and $50 \mathrm{~kg} \cdot \mathrm{ha}^{-1} \mathrm{~N}$ from urea on 14 and 28 Oct. 2005.

Application rates and timings at both sites were similar to those evaluated in Maryland in 2005 and are footnoted in the appropriate data tables. Herbicide treatments were applied on 7 Oct. when a majority of the CBG and PRG seedlings were in the two leaf to two tiller and four leaf to two tiller stage, respectively. When treatments were applied 4 WASE, CBG and PRG seedlings were three leaf to three tiller and two to five tiller, respectively. The site was first mowed to a height of $2.0 \mathrm{~cm}$ with a real mower on 10 Oct. Thereafter, the site was mowed three times per week to a height of $1.3 \mathrm{~cm}$ with a triplex reel mower and clippings were removed.
At all sites, plots were $1.5 \times 1.5 \mathrm{~m}$ and were arranged in a randomized complete block with four replications. All treatments were applied in $467 \mathrm{~L} \cdot \mathrm{ha}^{-1}$ water using a $\mathrm{CO}_{2}$ pressurized (262 kPa) sprayer equipped with an $8004 \mathrm{E}$ nozzle. The percent of plot area covered by CBG or PRG was rated visually on a $0 \%$ to $100 \%$ linear scale in which $0=$ no green cover and $100=$ entire plot area green. Injury to seedlings was rated on a 0 to 5 scale in which $0=$ no injury; $2.5=$ moderately severe injury and objectionable discoloration; and $5.0=$ extremely severe injury and seedling necrosis. Based on plots of the residuals, percent cover data were square root transformed. Data were subjected to the analysis of variance and significantly different means were separated at $P \leq 0.05$ using Tukey's protected least significant difference test. Preplanned orthogonal contrasts also were evaluated for cover data recorded on the final rating date in 2005 using the Estimate procedure in SAS (SAS statistical software; SAS Institute, Cary, NC).

\section{Results}

All of the data collected are not shown for reasons of brevity and when appropriate, it will hereafter be referred to as "some data not shown" or "data not shown." Only cover data in 2004 are discussed to further reduce article length. It also should be noted that there was little or no annual bluegrass in any of the study sites.

Maryland 2004. The CBG was rendered chlorotic by sequential applications of BPS. Bispyribac-sodium had no adverse effect on CBG cover throughout the rating period (Table 1; some data not shown). Ethofumesate, however, reduced CBG cover significantly on 15 Oct. and 2 and 28 Nov. (some data not shown). The reduction in cover caused by ETHO was only $1.0 \%$ when compared with the control. All plots had nearly achieved $100 \%$ CBG cover by 18 Nov. and plots were completely covered when last evaluated on 18 Apr. 2005 (data not shown).

Except for BPS applied at 49 or $49+$ $49 \mathrm{~g} \cdot \mathrm{ha}^{-1}$ a.i., most BPS treatments were asso- ciated with a reduction of PRG cover between 8 Oct. and 28 Nov. (Table 1; some data not shown). On 28 Nov., significant cover reductions were observed in PRG treated with $74+$ 74,111 , and $148 \mathrm{~g} \cdot \mathrm{ha}^{-1}$ a.i. $(93.8 \%$ to $95.3 \%$ cover) versus the control ( $98 \%$ cover). Ethofumesate did not reduce PRG cover during the experimental period. By 18 Apr. 2005, PRG cover in all herbicide-treated plots was similar to the control (data not shown).

Data from 2004 showed that BPS and ETHO caused yellowing and some reduction in cover in CBG and PRG treated 4 WASE. By Spring 2005, CBG and PRG cover in all herbicide-treated plots was equivalent to the control. In Fall 2005, rates were adjusted and treatments were applied 2 and 4 weeks after seedling emergence to better identify the safety window for using these herbicides on young $\mathrm{CBG}$ and PRG stands.

Maryland 2005. Injury caused by BPS in CBG and PRG appeared as stunted and chlorotic growth. Plots treated 2 WASE at BPS rates greater than $25+25 \mathrm{~g} \cdot \mathrm{ha}^{-1}$ a.i. sustained moderate (greater than 2.0) to severe (greater than 2.5) injury between 6 and 21 Oct. (Table 2). Plots treated 4 WASE sustained less injury and seedlings generally were injured at a moderate to moderately severe level on 14 Oct. only. The most severe injury was observed in plots treated with 148 g.ha ${ }^{-1}$ a.i. 2 WASE, but seedlings exhibited injury levels equivalent to most other treatments by 28 Oct. Ethofumesate applied 2 WASE moderately injured CBG seedlings (1.5 to 2.3) when plots were rated on 14,21 , and 28 Oct. but caused only a low level of injury (1.1 to 1.3 ) when applied 4 WASE.

Bispyribac-sodium applied to $\mathrm{CBG} 2$ WASE at $148 \mathrm{~g} \cdot \mathrm{ha}^{-1}$ a.i. reduced cover on all rating dates between 14 Oct. and 1 Dec. (Table 2). Plots treated with BPS at $74+74$ g.ha ${ }^{-1}$ a.i. exhibited a reduction in cover on 28 Oct., but no other BPS treatment (except $148 \mathrm{~g} \cdot \mathrm{ha}^{-1}$ a.i.) applied 2 WASE reduced cover significantly when compared with untreated plots. Bispyribac-sodium applied 4 WASE had no significant effect on CBG cover regardless of rate on all dates. Ethofumesate applied 2 WASE reduced CBG cover only on 28 Oct., but the herbicide caused no reduction in CBG cover on any rating date when applied 4 WASE. Orthogonal contrasts were calculated on data collected 1 Dec. Contrasts showed that BPS applied 2 WASE was more injurious to CBG versus ETHO, and the single high rate of BPS was more injurious to seedlings than sequential BPS treatments (Table 3). There were no CBG cover differences between plots treated with BPS 2 versus 4 WASE or BPS versus ETHO 4 WASE. The study site was last evaluated on 14 Apr. 2006, and all plots exhibited greater than $99 \%$ CBG cover (data not shown).

The low BPS rate $\left(25+25 \mathrm{~g} \cdot \mathrm{ha}^{-1}\right.$ a.i. $)$ and ETHO caused only minor injury to PRG seedlings when applied 2 WASE (Table 4). All other BPS treatments applied 2 WASE elicited moderately severe levels of PRG seedling injury on 6 Oct., which was 2 weeks after the initial treatment. Thereafter, there were few 
Table 2. 'Providence' creeping bentgrass injury and cover in response to bispyribac-sodium (bispyribac) and ethofumesate applied at various rates and two timings, College Park, MD, 2005.

\begin{tabular}{|c|c|c|c|c|c|c|c|c|c|c|}
\hline \multirow{2}{*}{ Herbicide } & \multirow{2}{*}{$\begin{array}{c}\text { Rate }^{\mathrm{z}} \\
\left.\text { (g.ha- }{ }^{-1} \text { a.i. }\right)\end{array}$} & \multirow{2}{*}{\multicolumn{5}{|c|}{$\begin{array}{ll}\text { Injury }^{y} & \\
14 \text { Oct. } & 21 \text { Oct. }\end{array}$}} & \multicolumn{4}{|c|}{ Cover $^{x}$} \\
\hline & & & & & & & 14 Oct. & 28 Oct. & 5 Nov. & 1 Dec. \\
\hline$\overline{\text { Bispyribac } 80 \mathrm{WP}}$ & $25+25$ & $2+4$ & $1.1 \mathrm{c}^{\mathrm{w}}$ & $1.5 \mathrm{bc}$ & $0.5 \mathrm{~cd}$ & $0.3 \mathrm{~cd}$ & $78 \mathrm{a}^{\mathrm{z}}$ & $84 a b$ & $85 \mathrm{a}$ & $93 \mathrm{a}$ \\
\hline Bispyribac 80WP & $49+49$ & $2+4$ & $2.2 \mathrm{~b}$ & $2.4 \mathrm{bc}$ & $1.5 \mathrm{bcd}$ & $0.7 \mathrm{bcd}$ & $74 \mathrm{a}$ & $77 \mathrm{ab}$ & $81 \mathrm{ab}$ & $90 \mathrm{a}$ \\
\hline Bispyribac 80WP & 148 & 2 & $3.9 \mathrm{a}$ & $4.5 \mathrm{a}$ & $3.8 \mathrm{a}$ & $1.9 \mathrm{ab}$ & $56 \mathrm{~b}$ & $58 \mathrm{c}$ & $63 \mathrm{~b}$ & $71 \mathrm{~b}$ \\
\hline Ethofumesate $1.5 \mathrm{EC}$ & $840+840$ & $2+4$ & $0.8 \mathrm{~cd}$ & $2.3 \mathrm{bc}$ & $2.2 \mathrm{~b}$ & $1.5 \mathrm{abc}$ & $72 \mathrm{a}$ & $74 \mathrm{~b}$ & $75 \mathrm{ab}$ & $93 \mathrm{a}$ \\
\hline Bispyribac 80WP & $25+25$ & $4+6$ & - v $^{\mathrm{v}}$ & $2.1 \mathrm{bc}$ & $1.3 \mathrm{bcd}$ & $1.1 \mathrm{a}-\mathrm{d}$ & $78 \mathrm{a}$ & $86 \mathrm{ab}$ & $81 \mathrm{ab}$ & $92 \mathrm{a}$ \\
\hline Bispyribac 80WP & 148 & 4 & - & $2.6 \mathrm{bc}$ & $1.5 \mathrm{bcd}$ & $2.1 \mathrm{a}$ & $76 \mathrm{a}$ & $80 \mathrm{ab}$ & $82 \mathrm{ab}$ & $90 \mathrm{a}$ \\
\hline Ethofumesate $1.5 \mathrm{EC}$ & $840+840$ & $4+6$ & - & $1.1 \mathrm{c}$ & $1.3 \mathrm{bcd}$ & $1.1 \mathrm{a}-\mathrm{d}$ & $83 \mathrm{a}$ & $83 \mathrm{ab}$ & $82 \mathrm{ab}$ & $90 \mathrm{a}$ \\
\hline Untreated & - & - & $0.0 \mathrm{~d}$ & $1.1 \mathrm{c}$ & $0.2 \mathrm{~d}$ & $0.3 \mathrm{~d}$ & $81 \mathrm{a}$ & $88 \mathrm{a}$ & $90 \mathrm{a}$ & $97 \mathrm{a}$ \\
\hline
\end{tabular}

${ }^{2}$ Treatments initiated at 2 weeks after seedling emergence (WASE) were applied on 23 Sept. and sequential treatments were applied on 6 Oct. 2005. Treatments initiated at 4 weeks after seedling emergence were applied on 6 Oct. and sequential treatments were applied 21 Oct. 2005.

'Injury was rated visually on a 0 to 5 scale in which $0=$ entire plot area green and healthy, $2.5=$ unacceptable injury for a fairway, and $5=$ entire plot brown or dead. ${ }^{\mathrm{x}}$ Creeping bentgrass cover was assessed visually on a linear $0 \%$ to $100 \%$ scale in which $0=$ entire plot area brown or dead and $100=$ entire plot area green. Percent cover data were transformed, but actual means are shown.

wMeans in a column followed by the same letter are not significantly different $(P \leq 0.05)$ according to Tukey's protected least significant difference test.

"Treatments applied later as noted previously.

significant or notable PRG injury differences among all 2 WASE herbicide treatments. Similar results were observed among four WASE treatments. The $148 \mathrm{~g} \cdot \mathrm{ha}^{-1}$ a.i. rate of BPS was most injurious in both timings, but plots treated 2 WASE recovered more rapidly. Like CBG, BPS applied to PRG 2 WASE at $148 \mathrm{~g} \cdot \mathrm{ha}^{-1}$ a.i. reduced cover on all rating dates (Table 4). When compared with the control, the $49+49 \mathrm{~g} \cdot \mathrm{ha}^{-1}$ a.i. rate
Table 3. Orthogonal contrasts among application timing and herbicide rate treatments for percent creeping bentgrass and perennial ryegrass cover data obtained on the final rating date in 2005 in College Park, MD, and Storrs, CT.

\begin{tabular}{|c|c|c|c|c|}
\hline \multirow[b]{3}{*}{ Contrast $^{\mathrm{z}}$} & \multicolumn{4}{|c|}{ Percent cover } \\
\hline & \multicolumn{2}{|c|}{ Creeping bentgrass } & \multicolumn{2}{|c|}{ Perennial ryegrass } \\
\hline & $\begin{array}{l}\text { Storrs, } \\
18 \text { Nov. }\end{array}$ & $\begin{array}{c}\text { College Park, } \\
1 \text { Dec. }\end{array}$ & $\begin{array}{l}\text { Storrs, } \\
18 \text { Nov. }\end{array}$ & $\begin{array}{c}\text { College Park, } \\
1 \text { Dec. }\end{array}$ \\
\hline$\overline{\text { BPS2 vs. BPS4 }}$ & $* * *$ & NS & $* *$ & NS \\
\hline BPS2 vs. ETHO2 & $* * *$ & $*$ & $* * *$ & $* * *$ \\
\hline BPS4 vs. ETHO4 & $* * *$ & NS & $*$ & $*$ \\
\hline BPS Seq. vs. BPS Sing & NS & $* * *$ & NS & $* * *$ \\
\hline BPS vs. ETHO & $* * *$ & NS & $* * *$ & $* * *$ \\
\hline BPS2 Seq vs. BPS4 Seq & $*$ & NS & $* * *$ & $*$ \\
\hline BPS2 Sing vs. BPS4 Sing & $* * *$ & $* * *$ & NS & $* * *$ \\
\hline
\end{tabular}

${ }^{\mathrm{z}} \mathrm{BPS}=$ bispyribac-sodium; ETHO $=$ ethofumesate; $2=$ application made 2 weeks after seedling emergence; 4 = applications made 4 weeks after seedling emergence; Sing = BPS treatments applied only once; Seq $=$ BPS treatments applied twice.

Ns,*, ${ }^{* *},{ }^{* * *}$ Nonsignificant or significant at $P \leq 0.05, \leq 0.01$, and $\leq 0.001$, respectively. of BPS reduced PRG cover on 5 Nov. and 1 Dec., whereas plots treated with $74+74$ g.ha ${ }^{-1}$ a.i. exhibited reduced cover on 5 Nov. No reduction in PRG cover was associated with any BPS treatment applied 4 WASE until 28 Oct. (i.e., $7 \mathrm{~d}$ after the sequential application). All PRG plots treated sequentially at 4 WASE with BPS at $49 \mathrm{~kg} \cdot \mathrm{ha}^{-1}$ or greater exhibited a significant reduction in cover on 28 Oct. and 5 Nov. Only plots treated with BPS at $49+49$ g.ha ${ }^{-1}$ a.i. 2 and 4 WASE and $148 \mathrm{~g} \cdot \mathrm{ha}^{-1}$ a.i. 2 WASE continued to show reduced PRG cover from the untreated plots on 1 Dec. Ethofumesatetreated plots, regardless of treatment timing, had cover ratings similar to untreated PRG plots on all rating dates. Orthogonal contrasts were calculated on data collected 1 Dec. (Table 3). Bispyribac-sodium applied 2 and 4 WASE resulted in similar PRG cover ratings. Plots treated with BPS 2 or 4 WASE had less cover than ETHO-treated plots. Regardless of timing, the single high rate of BPS was more injurious than the sequential

Table 4. 'Catalina II' perennial ryegrass injury and cover in response to bispyribac-sodium (bispyribac) and ethofumesate applied at various rates and two timings, College Park, MD, 2005.

\begin{tabular}{|c|c|c|c|c|c|c|c|c|c|c|}
\hline & & & \multirow{2}{*}{\multicolumn{4}{|c|}{\begin{tabular}{l}
\multicolumn{2}{c}{ Injury $^{y}$} \\
14 Oct. 2
\end{tabular}}} & \multicolumn{4}{|c|}{ Cover $^{x}$} \\
\hline Herbicide & $\begin{array}{c}\text { Rate } \\
\text { (g.ha- }{ }^{-1} \text { a.i.) }\end{array}$ & WASE $^{z}$ & & & & & 14 Oct. & 28 Oct. & 5 Nov. & 1 Dec. \\
\hline Bispyribac 80WP & $25+25$ & $2+4$ & $1.5 \mathrm{bc}^{\mathrm{w}}$ & $0.3 \mathrm{~cd}$ & $0.4 \mathrm{~d}$ & $0.1 \mathrm{de}$ & $71 \mathrm{ab}^{\mathrm{w}}$ & $73 \mathrm{a}-\mathrm{d}$ & $79 \mathrm{ab}$ & $89 \mathrm{ab}$ \\
\hline Bispyribac 80WP & $49+49$ & $2+4$ & $2.6 \mathrm{ab}$ & $0.5 \mathrm{~cd}$ & $0.8 \mathrm{~cd}$ & $0.2 \mathrm{de}$ & $65 \mathrm{bc}$ & $72 a-d$ & $73 \mathrm{bc}$ & $82 \mathrm{c}$ \\
\hline Bispyribac 80WP & 148 & 2 & $3.9 \mathrm{a}$ & $0.3 \mathrm{~cd}$ & $1.7 \mathrm{abc}$ & $0.8 \mathrm{bc}$ & $60 \mathrm{~d}$ & $63 \mathrm{~d}$ & $62 \mathrm{~d}$ & $73 \mathrm{~d}$ \\
\hline Ethofumesate $1.5 \mathrm{EC}$ & $840+840$ & $2+4$ & $0.6 \mathrm{c}$ & $0.0 \mathrm{~d}$ & $0.1 \mathrm{~d}$ & $0.0 \mathrm{e}$ & $73 \mathrm{a}$ & $76 \mathrm{abc}$ & $78 \mathrm{ab}$ & $92 \mathrm{a}$ \\
\hline Bispyribac 80WP & $25+25$ & $4+6$ & $-^{\mathrm{v}}$ & $0.9 \mathrm{bcd}$ & $1.1 \mathrm{bcd}$ & $0.8 \mathrm{bc}$ & $73 \mathrm{a}$ & $69 \mathrm{a}-\mathrm{d}$ & $74 \mathrm{bc}$ & $85 \mathrm{bc}$ \\
\hline Bispyribac 80WP & 148 & 4 & - & $2.0 \mathrm{a}$ & $2.3 \mathrm{a}$ & $1.9 \mathrm{a}$ & $68 \mathrm{ab}$ & $65 \mathrm{~d}$ & $67 \mathrm{~cd}$ & $84 \mathrm{bc}$ \\
\hline Ethofumesate $1.5 \mathrm{EC}$ & $840+840$ & $4+6$ & - & $0.0 \mathrm{~d}$ & $0.8 \mathrm{~cd}$ & $0.0 \mathrm{e}$ & $70 \mathrm{ab}$ & $78 \mathrm{ab}$ & $69 \mathrm{ab}$ & $86 \mathrm{bc}$ \\
\hline Untreated & - & - & $0.6 \mathrm{c}$ & $0.1 \mathrm{~cd}$ & $0.2 \mathrm{~d}$ & $0.0 \mathrm{e}$ & $72 \mathrm{ab}$ & $79 \mathrm{a}$ & $83 \mathrm{a}$ & $89 \mathrm{ab}$ \\
\hline
\end{tabular}

${ }^{2}$ Treatments initiated at 2 weeks after seedling emergence (WASE) were applied on 23 Sept. and sequential treatments were applied on 6 Oct. 2005. Treatments initiated at 4 weeks after seedling emergence were applied on 6 Oct. and sequential treatments were applied 21 Oct. 2005.

${ }^{y}$ Injury was rated visually on a 0 to 5 scale in which $0=$ entire plot green and healthy, $2.5=$ unacceptable injury for a fairway, and $5=$ entire plot brown or dead. ${ }^{x}$ Perennial ryegrass cover was assessed visually on a linear $0 \%$ to $100 \%$ scale in which $0=$ entire plot area brown or dead and $100=$ entire plot area green. Percent cover data were transformed, but actual means are shown.

"Means in a column followed by the same letter are not significantly different $(P \leq 0.05)$ according to Tukey's protected least significant difference test.

vTreatments applied later as noted previously. 
BPS treatments. The site was last evaluated on 14 Apr. 2006 and PRG cover ratings were nearly $100 \%$ in all plots (data not shown).

Connecticut 2005. Plots treated with BPS ( $74 \mathrm{~g} \cdot \mathrm{ha}^{-1}$ a.i. or greater) caused moderately severe to severe injury to both CBG and PRG within 1 week of applications (Tables 5 and 6). On 15 Oct., CBG and PRG treated with 49 g.ha ${ }^{-1}$ a.i. or less BPS exhibited moderate injury (1.0 to 2.3 ) when compared with the control. Plots treated with ETHO 2 WASE caused significant injury to CBG between 15 and 28 Oct., but CBG treated 4 WASE with ETHO exhibited only minor injury that was not different from the untreated control (Table 5). Chlorosis was noted in CBG plots treated with sequential BPS applications, which increased with herbicide rate. By 11 Nov., little to no injury was observed within CBG plots treated 2 WASE with BPS at 148 g.ha ${ }^{-1}$ a.i or ETHO. On 11 Nov., all CBG and PRG plots treated with single (148 g.ha ${ }^{-1}$ a.i.) or sequential (all rates) applications of BPS at 4 WASE exhibited moderate to severe injury (2.3 to 4.0 ) (Tables 5 and 6). Injury was not observed in PRG treated with ETHO regardless of rate or application timing.

Unlike the Maryland site, BPS reduced CBG cover from 28 Oct. 2005 to 5 May 2006 (Table 5). Bispyrabac reduced CBG cover by 28 Oct. and 11 Nov. when applied 2 and 4 WASE, respectively. Only plots treated with ETHO 4 WASE had cover ratings equivalent to the control on all rating dates in 2005 . From contrasts, all BPS treatments were more injurious than ETHO (Table 3). On 5 May 2006, CBG cover within all herbicide-treated plots ranged from $2 \%$ to $32 \%$ (Table 5 ).

When BPS was applied to PRG, a slight reduction in turf cover was initially observed. Significant reductions in PRG cover continued to be observed between 28 Oct. and 18 Nov. within plots treated 2 WASE with BPS rates $49 \mathrm{~g} \cdot \mathrm{ha}^{-1}$ a.i. or greater (Table 6).
Additionally, PRG treated 4 WASE with 74 $\mathrm{g} \cdot \mathrm{ha}^{-1}$ a.i. or greater exhibited a reduction in cover $(76 \%$ to $79 \%)$ when compared with the control $(92 \%)$ on 18 Nov. From contrasts, BPS caused a greater reduction in PRG cover regardless of timing when compared with ETHO (Table 3). Plots treated 2 WASE with BPS had less PRG cover than plots treated 4 WASE. On 5 May 2006, PRG plots treated sequentially 4 WASE with BPS at $25 \mathrm{~g} \cdot \mathrm{ha}^{-1}$ a.i. and ETHO had similar cover to the control (Table 6). Throughout the study, ETHO and the low rate of BPS generally had no adverse effect on PRG cover.

\section{Discussion}

Bispyrabac-sodium and ETHO were applied to seedlings at rates labeled for use on established CBG and PRG. The exception was $148 \mathrm{~g} \cdot \mathrm{ha}^{-1}$ a.i. BPS rate, which was intended to simulate injury from an overlap

Table 5. 'Putter' creeping bentgrass injury and cover in response to bispyribac-sodium (bispyribac) and ethofumesate applied at various rates and two timings, Storrs, CT, 2005.

\begin{tabular}{|c|c|c|c|c|c|c|c|c|c|c|}
\hline \multirow[b]{4}{*}{ Herbicide } & \multirow{4}{*}{$\begin{array}{c}\text { Rate } \\
\text { (g.ha }{ }^{-1} \text { a.i.) }\end{array}$} & \multirow[b]{4}{*}{$\mathrm{WASE}^{\mathrm{z}}$} & \multirow{2}{*}{\multicolumn{4}{|c|}{ Injury $^{\mathrm{y}}$}} & \multicolumn{4}{|c|}{ Cover $^{\mathrm{x}}$} \\
\hline & & & & & & & \multicolumn{3}{|c|}{2005} & \multirow{3}{*}{2006} \\
\hline & & & 15 Oct. & 28 Oct. & 11 Nov. & 18 Nov. & 28 Oct. & 11 Nov. & 18 Nov. & \\
\hline & & & \multicolumn{4}{|c|}{ 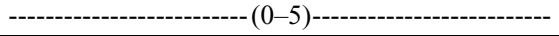 } & \multicolumn{3}{|c|}{ 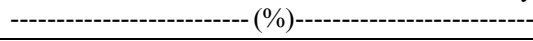 } & \\
\hline Bispyribac 80WP & $25+25$ & $2+4$ & $1.0 \mathrm{c}^{\mathrm{w}}$ & $1.5 \mathrm{bc}$ & $2.3 \mathrm{c}$ & $1.0 \mathrm{c}$ & $23 \mathrm{~b}-\mathrm{e}$ & $24 \mathrm{~cd}$ & $32 \mathrm{bc}$ & $11 \mathrm{~cd}$ \\
\hline Bispyribac 80WP & $49+49$ & $2+4$ & $1.8 \mathrm{bc}$ & $2.0 \mathrm{~b}$ & $3.5 \mathrm{ab}$ & $2.8 \mathrm{~b}$ & 22 cde & $17 \mathrm{~cd}$ & $16 \mathrm{cde}$ & 7 cde \\
\hline Bispyribac 80WP & $74+74$ & $2+4$ & $2.5 \mathrm{~b}$ & $2.5 \mathrm{ab}$ & $4.0 \mathrm{a}$ & $3.5 \mathrm{ab}$ & $23 \mathrm{c}-\mathrm{e}$ & $11 \mathrm{~d}$ & $13 \mathrm{de}$ & $6 \mathrm{cde}$ \\
\hline Bispyribac 80WP & 148 & 2 & $3.8 \mathrm{a}$ & $3.3 \mathrm{a}$ & $0.0 \mathrm{~d}$ & $0.0 \mathrm{c}$ & $15 \mathrm{e}$ & $20 \mathrm{~cd}$ & $24 \mathrm{bcd}$ & $17 \mathrm{bc}$ \\
\hline Ethofumesate 1.5EC & $840+840$ & $2+4$ & $3.5 \mathrm{a}$ & $2.3 \mathrm{ab}$ & $0.5 \mathrm{~d}$ & $0.0 \mathrm{c}$ & $20 \mathrm{de}$ & $29 \mathrm{bc}$ & $36 \mathrm{~b}$ & $29 \mathrm{~b}$ \\
\hline Bispyribac 80WP & $25+25$ & $4+6$ & $\underline{\mathrm{v}}^{\mathrm{v}}$ & $0.3 \mathrm{~d}$ & $2.5 \mathrm{bc}$ & $2.5 \mathrm{~b}$ & $37 \mathrm{ab}$ & $29 \mathrm{bc}$ & $24 \mathrm{bcd}$ & 7 cde \\
\hline Bispyribac $80 \mathrm{WP}$ & $49+49$ & $4+6$ & - & $0.5 \mathrm{~cd}$ & $3.3 \mathrm{abc}$ & $4.3 \mathrm{a}$ & $35 \mathrm{abc}$ & $23 \mathrm{~cd}$ & $12 \mathrm{de}$ & $2 \mathrm{e}$ \\
\hline Bispyribac $80 \mathrm{WP}$ & $74+74$ & $4+6$ & - & $0.8 \mathrm{~cd}$ & $4.0 \mathrm{a}$ & $4.3 \mathrm{a}$ & $30 \mathrm{a}-\mathrm{d}$ & $15 \mathrm{~cd}$ & $6 \mathrm{e}$ & $2 \mathrm{e}$ \\
\hline Bispyribac 80WP & 148 & 4 & - & $0.5 \mathrm{~cd}$ & $4.0 \mathrm{a}$ & $4.5 \mathrm{a}$ & $33 \mathrm{a}-\mathrm{d}$ & $17 \mathrm{~cd}$ & 8 e & $4 \mathrm{de}$ \\
\hline Ethofumesate 1.5EC & $840+840$ & $4+6$ & - & $0.8 \mathrm{~cd}$ & $0.3 \mathrm{~d}$ & $0.3 \mathrm{c}$ & $33 \mathrm{a}-\mathrm{d}$ & $44 \mathrm{ab}$ & $64 \mathrm{a}$ & $32 \mathrm{~b}$ \\
\hline Untreated & - & - & $0.0 \mathrm{~d}$ & $0.0 \mathrm{~d}$ & $0.0 \mathrm{~d}$ & $0.0 \mathrm{c}$ & $42 \mathrm{a}$ & $51 \mathrm{a}$ & $76 \mathrm{a}$ & $74 \mathrm{a}$ \\
\hline
\end{tabular}

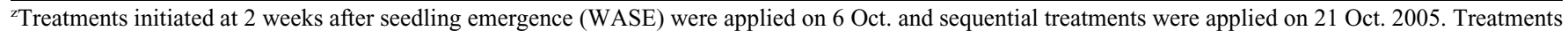
initiated at 4 weeks after seedling emergence were applied on 21 Oct. and sequential treatments were applied 4 Nov. 2005.

${ }^{\mathrm{y}}$ Injury was rated visually on a 0 to 5 scale in which $0=$ entire plot green and healthy, $2.5=$ unacceptable injury for a fairway, and $5=$ entire plot brown or dead. ${ }^{\mathrm{x}}$ Creeping bentgrass cover was assessed visually on a linear $0 \%$ to $100 \%$ scale in which $0=$ entire plot area brown or dead and $100=$ entire plot area green. Percent cover data were transformed, but actual means are shown.

${ }^{\text {w}}$ Means in a column followed by the same letter are not significantly different $(P \leq 0.05)$ according to Tukey's protected least significant difference test.

vTreatments applied later as noted previously.

Table 6. 'Amazing' perennial ryegrass injury and cover in response to bispyribac-sodium (bispyribac) and ethofumesate applied at various rates and timings, Storrs, CT, 2005.

\begin{tabular}{|c|c|c|c|c|c|c|c|c|c|c|}
\hline \multirow[b]{4}{*}{ Herbicide } & \multirow{4}{*}{$\begin{array}{c}\text { Rate } \\
\text { (g.ha }{ }^{-1} \text { a.i.) }\end{array}$} & \multirow[b]{4}{*}{ WASE $^{\mathrm{z}}$} & \multirow{2}{*}{\multicolumn{4}{|c|}{ Injury $^{\mathrm{y}}$}} & \multicolumn{4}{|c|}{ Percent cover ${ }^{\mathrm{x}}$} \\
\hline & & & & & & & \multicolumn{3}{|c|}{2005} & \multirow{3}{*}{$\frac{2006}{5 \text { May }}$} \\
\hline & & & 15 Oct. & 28 Oct. & 11 Nov. & 18 Nov. & 28 Oct. & 11 Nov. & 18 Nov. & \\
\hline & & & \multicolumn{4}{|c|}{ 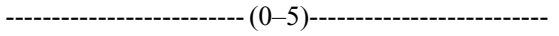 } & \multirow{2}{*}{\multicolumn{4}{|c|}{ 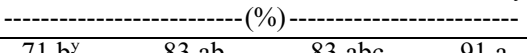 }} \\
\hline Bispyribac 80WP & $25+25$ & $2+4$ & $1.5 \mathrm{~b}^{\mathrm{w}}$ & $1.5 \mathrm{~b}$ & $2.0 \mathrm{c}$ & $1.0 \mathrm{~d}$ & $71 \mathrm{~b}^{\mathrm{y}}$ & $83 \mathrm{ab}$ & & \\
\hline Bispyribac 80WP & $49+49$ & $2+4$ & $2.3 \mathrm{~b}$ & $1.5 \mathrm{~b}$ & $2.0 \mathrm{c}$ & $1.3 \mathrm{~cd}$ & $73 \mathrm{~b}$ & $75 \mathrm{bc}$ & $74 \mathrm{~cd}$ & $85 \mathrm{ab}$ \\
\hline Bispyribac 80WP & $74+74$ & $2+4$ & $3.3 \mathrm{a}$ & $3.0 \mathrm{a}$ & $3.8 \mathrm{a}$ & $2.3 \mathrm{~b}$ & $64 \mathrm{~b}$ & $66 \mathrm{c}$ & $66 \mathrm{~d}$ & $70 \mathrm{c}$ \\
\hline Bispyribac 80WP & 148 & 2 & $3.8 \mathrm{a}$ & $3.3 \mathrm{a}$ & $0.5 \mathrm{~d}$ & $0.0 \mathrm{e}$ & $64 \mathrm{~b}$ & $76 \mathrm{bc}$ & $78 \mathrm{bc}$ & $86 \mathrm{ab}$ \\
\hline Ethofumesate $1.5 \mathrm{EC}$ & $840+840$ & $2+4$ & $0.0 \mathrm{c}$ & $0.0 \mathrm{c}$ & $0.0 \mathrm{~d}$ & $0.0 \mathrm{e}$ & $85 \mathrm{a}$ & 92 a & $86 \mathrm{ab}$ & $97 \mathrm{a}$ \\
\hline Bispyribac 80WP & $25+25$ & $4+6$ & $-^{\mathrm{v}}$ & $0.3 \mathrm{bc}$ & $2.3 \mathrm{bc}$ & $2.1 \mathrm{bc}$ & $86 \mathrm{a}$ & $90 \mathrm{a}$ & 84 abc & $87 \mathrm{ab}$ \\
\hline Bispyribac 80WP & $49+49$ & $4+6$ & - & $0.3 \mathrm{bc}$ & $3.0 \mathrm{ab}$ & $2.5 \mathrm{~b}$ & $86 \mathrm{a}$ & $86 \mathrm{ab}$ & $82 \mathrm{abc}$ & $74 \mathrm{bc}$ \\
\hline Bispyribac 80WP & $74+74$ & $4+6$ & - & $0.5 \mathrm{bc}$ & $2.8 \mathrm{bc}$ & $2.8 \mathrm{ab}$ & $83 \mathrm{a}$ & $86 \mathrm{ab}$ & $76 \mathrm{bc}$ & $66 \mathrm{c}$ \\
\hline Bispyribac 80WP & 148 & 4 & - & $0.1 \mathrm{bc}$ & $2.8 \mathrm{bc}$ & $3.5 \mathrm{a}$ & $84 \mathrm{a}$ & $87 \mathrm{ab}$ & 79 bc & $71 \mathrm{c}$ \\
\hline Ethofumesate $1.5 \mathrm{EC}$ & $840+840$ & $4+6$ & - & $0.0 \mathrm{c}$ & $0.0 \mathrm{~d}$ & $0.0 \mathrm{e}$ & $84 \mathrm{a}$ & $91 \mathrm{a}$ & $87 \mathrm{ab}$ & $90 \mathrm{a}$ \\
\hline Untreated & - & - & $0.0 \mathrm{c}$ & $0.0 \mathrm{c}$ & $0.0 \mathrm{~d}$ & $0.0 \mathrm{e}$ & $87 \mathrm{a}$ & $94 \mathrm{a}$ & $92 \mathrm{a}$ & $99 \mathrm{a}$ \\
\hline
\end{tabular}

${ }^{2}$ Treatments initiated at 2 weeks after seedling emergence (WASE) were applied on 6 Oct. and sequential treatments were applied on 21 Oct. 2005 . Treatments initiated at 4 weeks after seedling emergence were applied on 21 Oct. and sequential treatments were applied 4 Nov. 2005.

${ }^{\mathrm{y}}$ Injury was rated visually on a 0 to 5 scale in which $0=$ entire plot green and healthy, $2.5=$ unacceptable injury for a fairway, and $5=$ entire plot brown or dead. ${ }^{\mathrm{x}}$ Perennial ryegrass over was assessed visually on a linear $0 \%$ to $100 \%$ scale in which $0=$ entire plot area brown or dead and $100=$ entire plot area green. Percent cover data were transformed, but actual means are shown.

wMeans in a column followed by the same letter are not significantly different $(P \leq 0.05)$ according to Tukey's protected least significant difference test.

vTreatments applied later as noted previously. 
of the $74 \mathrm{~g} \cdot \mathrm{ha}^{-1}$ a.i. rate. The herbicides were applied twice, which also is recommended for annual bluegrass control. Rates of BPS in the range of 49 and $74 \mathrm{~g} \cdot \mathrm{ha}^{-1}$ a.i. applied twice were shown previously to provide a similar level of annual bluegrass control (McDonald et al., 2006). There was, however, little or no annual bluegrass in any of the study sites.

In both Connecticut and Maryland, BPS applied once at $148 \mathrm{~g} \cdot \mathrm{ha}^{-1}$ a.i. was too phototoxic to both CBG and PRG seedlings. In Maryland, BPS applied twice at rates between 25 to $74 \mathrm{~g} \cdot \mathrm{ha}^{-1}$ caused low to moderate CBG injury, but turf cover was similar to the control by early November in 2004 and 2005. Data collected the next spring showed no additional injury from herbicides occurred over winter in Maryland. Furthermore, BPS and ETHO were generally less injurious when applied at 4 WASE versus 2 WASE. In Connecticut, however, BPS was extremely phytotoxic to CBG seedlings. Ethofumesate applied 4 WASE appeared safe initially in Connecticut, but cover ratings obtained in May 2006 showed that ETHOtreated seedlings were injured over winter. In a greenhouse study, McCullough and Hart (2006) observed an increase in chlorosis in CBG when BPS-treated plots were maintained at $10{ }^{\circ} \mathrm{C}$ but less chlorosis and improved effectiveness in controlling annual bluegrass when applied 20 or $30{ }^{\circ} \mathrm{C}$. Similarly, Lycan and Hart (2006) observed that fall applications of BPS caused substantially more injury to mature CBG than summer applications. Hence, low temperatures in Connecticut during the fall study period may have increased the sensitivity of CBG seedlings to BPS. Severe BPS-induced injury to seedlings in Connecticut was evident as early as 11 Nov. 2005 (i.e., $36 \mathrm{~d}$ after the initial application). Average daily low temperatures during the $36-\mathrm{d}$ period after the initial 2005 application in Maryland (i.e., 23 Sept. to 27 Nov.) and Connecticut (i.e., 6 Oct. to 11 Nov.), however, were $1.7^{\circ} \mathrm{C}$ (range, -7.0 to $9.9^{\circ} \mathrm{C}$ ) and $6.8^{\circ} \mathrm{C}$ (range, -0.6 to 19.4 ${ }^{\circ} \mathrm{C}$ ), respectively. Because daily low temperatures during the aforementioned periods were cooler in Maryland than Connecticut, temperature-induced injury was unlikely. During the same time periods noted previously, however, total precipitation had been $298 \mathrm{~mm}$ in Connecticut and only $35 \mathrm{~mm}$ in Maryland. In Maryland in 2004, there was 63 $\mathrm{mm}$ of precipitation during the first $36 \mathrm{~d}$ (i.e., 24 Sept. to 29 Oct.) after herbicides were applied and the average low temperature during that period was $8.9{ }^{\circ} \mathrm{C}$ (range, 0.7 to $\left.19.8{ }^{\circ} \mathrm{C}\right)$. Hence, excessive soil moisture in 2005 may have played a significant role in predisposing CBG seedlings to severe injury from BPS in Connecticut. Increasing soil moisture was shown to increase BPS efficacy (Koger et al., 2007). Furthermore, watersaturated soils have been observed to lead to more BPS activity and increased annual bluegrass control as well as turf injury (Branham, personal communications). Therefore, saturated soil conditions in Connecticut likely enhanced BPS uptake by seedlings or in some other way caused the phytotoxicity observed. Hunter and Kealy (2005) also observed BPS (22.7 to $136.2 \mathrm{~g} \cdot \mathrm{ha}^{-1}$ a.i.) to be phytotoxic to $\mathrm{CBG}$ seedlings. In that greenhouse study, seedlings were maintained at $18{ }^{\circ} \mathrm{C}$, but they were covered with polythene to maintain moist soil during the germination period as well as during the period before BPS application. The BPS label also notes that turfgrass injury is more persistent under cool and cloudy conditions (Anonymous, 2005b). Hence, other factors such as light intensity and soil properties or their interactions may have contributed to the phytotoxicity observed in Connecticut with both BPS and ETHO.

Perennial ryegrass seedlings were tolerant of BPS applied at $25+25 \mathrm{~g} \cdot \mathrm{ha}^{-1}$ a.i. in both Connecticut and Maryland, but ETHO $(840+$ $840 \mathrm{~g} \cdot \mathrm{ha}^{-1}$ a.i.) generally was safer to apply. Given the potential for BPS to control annual bluegrass in seedling turf, the reduction in PRG cover likely would be considered an acceptable risk in situations in which there are annual bluegrass biotypes tolerant to ETHO. As previously observed in Maryland, ETHO caused relatively little injury to CBG seedlings when applied 4 WASE (Kaminski et al., 2004).

Field research is needed to assess herbicide efficacy on annual bluegrass in young CBG and PRG stands. Severe phytotoxicity to $\mathrm{CBG}$ seedlings in Connecticut indicates BPS and ETHO use poses a significant risk to turf establishment. Because annual bluegrass seedlings would likely outcompete immature $\mathrm{CBG}, \mathrm{BPS}$ use may be prudent. The influence of soil and air temperature, soil moisture, light intensity, and other environmental factors on BPS performance requires further study.

\section{Literature Cited}

Anonymous. 2005a. Prograss ${ }^{\circledR}$ herbicide label. EPA Reg. No. 432-941. Bayer Environmental Services, Montvale, NJ.
Anonymous. 2005b. Velocity ${ }^{\circledR}$ herbicide label. EPA Reg. No. 59639-130. Valent U.S.A. Corp., Walnut Creek, CA.

Askew, S.D. 2006. New herbicides for annual and roughstalk bluegrass control: Transition zone perspective. Proc. Northeast Weed Sci. Soc. 60:113.

Branham, B. and R. Calhoun. 2005. Velocity: Poa апnиa control at last? Golf Course Management 10:73-77.

Dernoeden, P.H. 2002. Creeping bentgrass management: Summer stresses, weeds and selected maladies. John Wiley \& Sons, Inc., Hoboken, NJ.

Dernoeden, P.H. and T.R. Turner. 1988. Annual bluegrass control and tolerance of Kentucky bluegrass and perennial ryegrass to ethofumesate. HortScience 23:565567.

Hunter, A. and E. Kealy. 2005. The influence of bispyribac-sodium on seedling Agrostis stolonifera var. 'Penn A4' growth and Poa annua L. control. International Turfgrass Soc. Res. J. 10:874-878

Kaminski, J.E., P.H. Dernoeden, and C.A Bigelow. 2004. Creeping bentgrass seedling tolerance to herbicides and paclobutrazol. HortScience 39:1126-1129.

Koger, C.H., D.M. Dodds, and D.B. Reynolds. 2007. Effect of adjuvants, and urea ammonium nitrate on bispyribac efficacy. I. Efficacy, rainfastness, and soil moisture. Weed Sci. 55: 399-405.

Lee, W.O. 1981. Control of annual bluegrass (Poa aпnиa) in perennial ryegrass (Lolium perenne) seed fields. Weed Sci. 29:444447.

Lycan, D.W. and S.E. Hart. 2005. Cool-season turfgrass response to bispyribac-sodium. HortScience 40:1552-1555.

Lycan, D.W. and S.E. Hart. 2006. Seasonal effects on annual bluegrass (Poa апnиа) control in creeping bentgrass with bispyribac-sodium. Weed Technology 20: 722-727.

McCullough, P.E. and S.E. Hart. 2006. Temperature influences creeping bentgrass (Agrostis stolonifera) and annual bluegrass (Poа аппиа) response to bispyribac-sodium. Weed Technology 20:728-732.

McDonald, S.J., P.H. Dernoeden, and J.E. Kaminski. 2006. Creeping bentgrass tolerance and annual bluegrass control with bispyribac-sodium tankmixed with iron and nitrogen. Applied Turfgrass Science.

Turgeon, A.J. 2008. Turfgrass management. 8th Ed. Pearson Prentice Hall, Upper Saddle River, NJ.

Vargas, J.M. and A.J. Turgeon. 2004. Poa annua John Wiley \& Sons, Inc., Hoboken, NJ.

Yelverton, F.H. and L.B. McCarty. 2001. Tolerance of perennial ryegrass and Роа аппиа control with herbicides in overseeded bermudagrass. International Turfgrass Soc. Res. J. 9:1050-1055. 